\title{
UDC 541.128
}

V.S. Yemelyanova, Zh.K. Kairbekov, T.V. Shakieva, N. Nemykina, B.T. Dosumova, U.N. Dzhatkambaeva

BSE Scientific Research Institute of New Chemical Technologies and Materials of the

RSE Kazakh National University named after al-Farabi

"E-mail: niinhtm@mail.ru

\section{The oxidative $p$-dichlorobenzene dechlorinating in the presence of copper (II) complexes and nitrogen (II, IV) oxides}

\begin{abstract}
The results of dechlorination in the solution CuCl2-TBP-NaNO2-O2-H2O kinetics research are presented in the article. All system components influence to the dechlorination process is studied and quantitatively described. The composition of copper intermediate complexes participating in reaction is studied by the instrumentality of UV-spectroscopy. Established part of binuclear copper complexes in the catalytic intermediate complex constants of formation were estimated and compared with the kinetic and spectrophotometric methods. The composition of the intermediate complexes responsible for process is defined, the mechanism scheme is offered, the p-dichlorobenzene dechlorination limiting stage including redox-disintegration of the intermediate complex consisting of dimeric complex of copper (II, I) chloride, nitrogen oxide and p-dichlorobenzene is defined.
\end{abstract}

Keywords: oxidation, dechlorination, p-dichlorbenzene, catalyst, kinetics, mechanism.

\section{Introduction}

Despitegradualreductionofthepolychlorbiphenyl (PCB) application in economic activities, it continue to pollute environment and the problem of aromatic compounds dechlorinating stands sharply enough.

The possibility of low-temperature $\left(40-60^{\circ} \mathrm{C}\right)$ oxidative dechlorinating is shown on the example of paradichlorobenzene in the present work and the kinetics of process described in details and studied quantitatively, conditions of it realization are optimised.

At the chemical methods of PCB neutralisation various reagents, conditions of reaction realization, catalytical systems and devices are applied including oxidative methods among which burning prevails. Among disadvantages of burning it is possible to note high cost, additional fuel consumption, fast deterioration of the equipment in the conditions of an aggressive environment $\left(\mathrm{Cl}_{2}\right.$ and $\left.\mathrm{HCl}\right)$ and high temperatures, and also irreversible loss of a hydrocarbonic component.

Some scattered works are devoted to researches in the area of PCB catalytical oxidation. Application of catalysts allows to reduce considerably process temperature and consequently to reduce capital and power expenses.

\section{Experimental part}

On the example of $p$-dichlorobenzene ( $p$-DCB) we have shown that in the presence of copper complex compound and nitrogen (II, IV) oxides it is possible to implement catalytical oxidative dechlorinating of $p$-DCB. Kinetics was studied in static conditions in a kinetic mode using the isothermal reactor equipped with the potentiometric device consisting of platinum and calomel halfelements. Reaction rate was monitored by rate of oxygen absorption $/ \mathrm{mol} / 1 \cdot \mathrm{s}$ in the system $p$-DCBTBP- $\mathrm{HCl}-\mathrm{CuCl}_{2}-\mathrm{NaNO}_{2}-\mathrm{O}_{2}-\mathrm{H}_{2} \mathrm{O}$.

Tributylphosphate has been chosen as solvent for $p$-dichlorobenzene besides molecules of the phosphoric acid tributyl ether $\left(\mathrm{C}_{4} \mathrm{H}_{9} \mathrm{O}\right){ }_{3} \mathrm{P}=\mathrm{O}$, (TBP) are capable to formation of donor-acceptor or dative bonds at the cost of phosphoryl atom of oxygen $p \pi$ orbital (HOMO). At that insinuating into coordination sphere of many compounds, they push out others ligands, in particular, hydrate water and derive these compounds in the organic phase. Therefore TBP is one of the most active and widespread extractant. It is applied in radiochemistry for uranium separation, for extraction of rare-earth elements, in analytical chemistry for division and concentrating of microimpurities. Low mutual solubility ( $3.4 \mathrm{~g} / \mathrm{l}$ of 
TBP in water and $64 \mathrm{~g} / 1$ of water in TBP) of system water-TBP promotes their good extraction property. At the cost of weak hydrogen bonds water and TBP form compound with composition 1:1, discovered in a benzene solution and characterized by the constant of stability equal $10.8 \mathrm{l} / \mathrm{mol}$ at $298^{\circ} \mathrm{K}$.

\section{The results and discussion}

The results of $\mathrm{p}$-dichlorobenzene dechlorination in the solution $\mathrm{CuCl}_{2}-\mathrm{TBP}-\mathrm{NaNO}_{2}-\mathrm{O}_{2}-\mathrm{H}_{2} \mathrm{O}$ kinetics research are presented in the article.

Typical conversion curves are is exposed in figure 1.

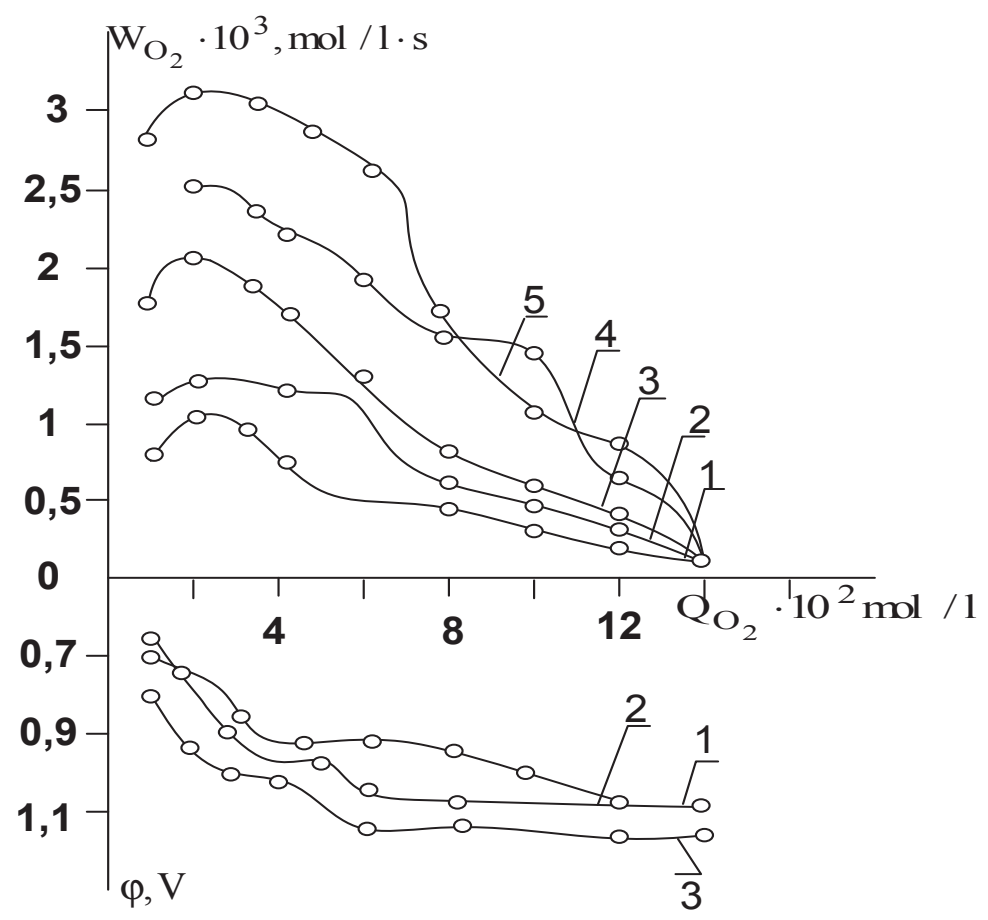

Figure 1 - $p$-dichlorobenzene oxidizing dechlorinating in the solution $\mathrm{HCl}-\mathrm{LiCl}-\mathrm{NaNO}_{2}-\mathrm{TBP}-\mathrm{H}_{2} \mathrm{O}$

Designation of the curves: $\mathrm{C}_{\mathrm{CuCl}} \cdot 10^{-2}: 1 .-1.0 ; 2 .-2.0 ; 3 .-3.0 ; 4 .-5.0 ; 5 .-10.0 \mathrm{~mol} / \mathrm{l}$

Oxidation conditions: $\mathrm{P}_{\mathrm{O}_{2}}=1 \mathrm{~atm} ., \mathrm{T}=333 \mathrm{~K}, \tilde{N}_{\mathrm{HCl}}=4.0 \mathrm{~mol} / \mathrm{l}, \tilde{N}_{\mathrm{HCl}}=4.0 \mathrm{~mol} / \mathrm{l}, \mathrm{C}_{\mathrm{NaNO}_{2}}=3 \cdot 10^{-2} \mathrm{~mol} / 1$,

$$
\mathrm{C}_{p-\mathrm{DCB}}=1 \cdot 10^{-2} \mathrm{~mol} / 1
$$

Conversion curves pass through a maximum to which the solution redox potential increase on $350-400 \mathrm{mv}$ corresponds on potentiometric curves. In the gas phase above the solution nitrogen oxides $\mathrm{NO}, \mathrm{NO}_{2}, \mathrm{~N}_{2} \mathrm{O}$ appear which identified IR- spectrophotometrically, using Specord-725 on intensive absorption bands $\left(\mathrm{cm}^{-1}\right): \mathrm{NO}_{2}(749,1318$, 1617), $\mathrm{NO}(1880)$ and $\mathrm{N}_{2} \mathrm{O}(2190,2220)$. The increase of bands intensity, characteristic for $\mathrm{NO}_{2}$ and fall of the $\mathrm{NO}$ bands intensity corresponds to the increase of oxygen absorption rate on conversion curves and to redox potential increase in the solution. The given fact allows to assume that autocatalytic character of curves is caused by occurrence $\mathrm{NO}_{2}$ as the result of $\mathrm{HNO}_{2}$ disproportionation and $\mathrm{NO}$ oxidation to $\mathrm{NO}_{2}$ by oxygen.

$$
\begin{gathered}
2 \mathrm{HNO}_{2} \rightarrow \mathrm{NO}_{2}+\mathrm{NO}+\mathrm{H}_{2} \mathrm{O} \\
2 \mathrm{NO}+\mathrm{O}_{2} \rightarrow \mathrm{NO}_{2}
\end{gathered}
$$

The basic part of process come about at the constant $\mathrm{NO}_{2}$ content in a gas phase, this fact allows to assume that the catalysis of $p$-dichlorobenzene oxidising dechlorinating is is linked to this particle. The redox potential value is in an interval $0.6-1.1 \mathrm{~V}$, except but $\mathrm{d} \varphi /$ da $\left(\mathrm{H}_{3} \mathrm{O}^{+}\right)>0, \mathrm{~d} \varphi / \mathrm{dN}_{\mathrm{NaNO}_{2}}>0$, $\mathrm{d} \phi / \mathrm{dC}_{\mathrm{CuCl}_{2}}>0$ (figure 1). According to it for the studied systems it is possible to present potential of an electrode in a kind:

$\varphi=1.09+\frac{R T}{F} \ln \frac{\left[\mathrm{NO}_{2}\right] \cdot\left[\mathrm{H}^{+}\right]}{\left[\mathrm{HNO}_{2}\right]}=0.54+\frac{R T}{F} \ln \frac{\left[\mathrm{Cu}^{2+}\right]}{\left[\mathrm{Cu}^{+}\right]}$ 

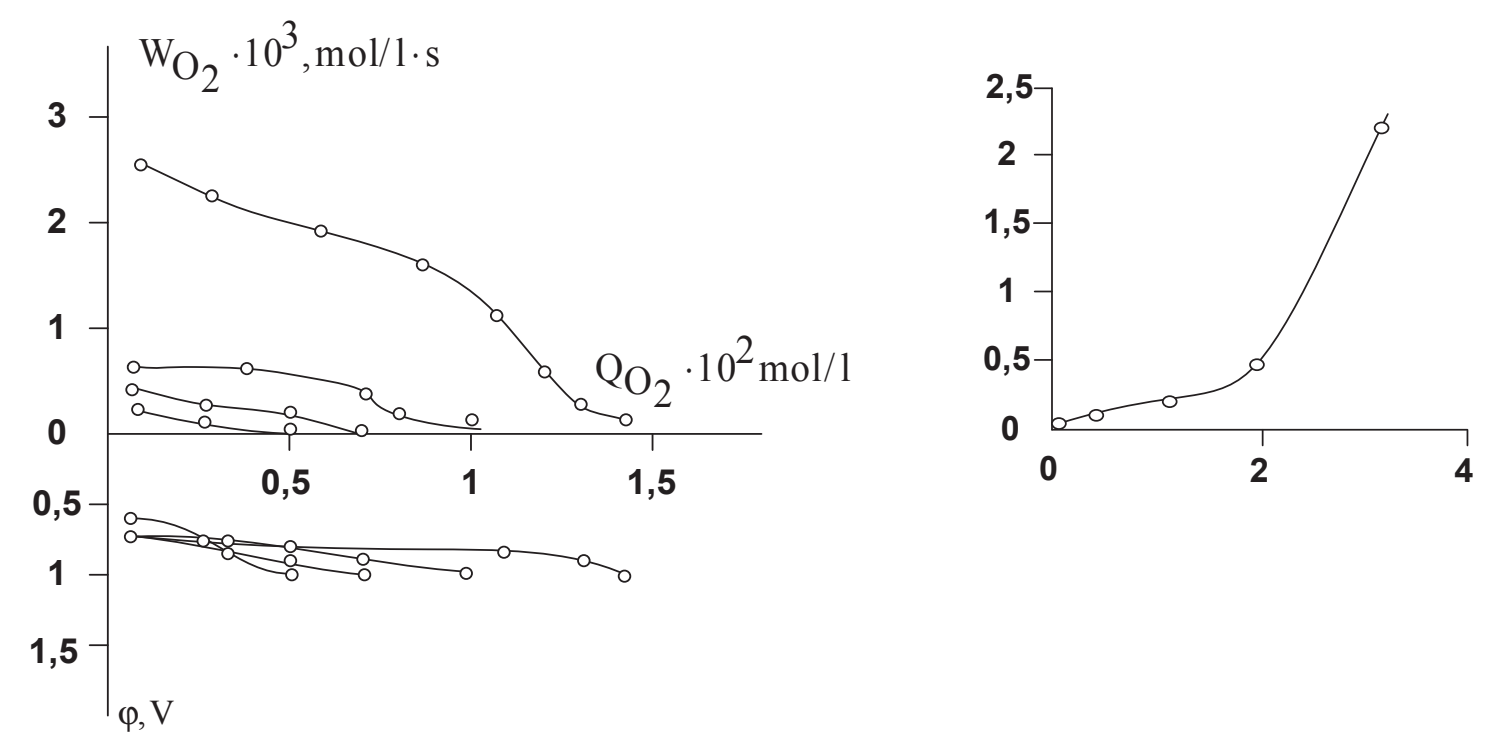

Figure 2 - The dependence of $p$-dichlorobenzene oxidising dechlorinating rate from the concentration of sodium nitrite in the solution: $\mathrm{HCl}-\mathrm{LiCl}-\mathrm{NaNO}_{2}-\mathrm{TBP}-\mathrm{H}_{2} \mathrm{O}$

Designation of curves: $\tilde{N}_{\text {NaNO }} \cdot 10^{2}: 1-0.5,2-1,2,3-2.4-3$

Oxidation conditions: $\mathrm{PO}_{2}=1 \mathrm{~atm} . \mathrm{T}=333 \mathrm{~K}, \mathrm{C}_{\mathrm{CuCl}_{2}}=1 \cdot 10^{-2} \mathrm{~mol} / 1, \mathrm{C}_{\mathrm{HCl}}=1,0 \mathrm{~mol} /, \mathrm{C}_{\mathrm{LiCl}}=3,0 \mathrm{~mol} / 1$,

$$
\mathrm{C}_{\mathrm{p}-\mathrm{DCB}}=1 \cdot 10^{-2} \mathrm{~mol} / 1
$$

The received value $\mathrm{k}$ is ten times more than the similar value presented for reaction (4) in the solution $\mathrm{NaNO}_{2}-\mathrm{H}_{2} \mathrm{O}$ and ten times less than the corresponding value in the solution $\mathrm{NaNO}_{2}-$ $\mathrm{NaAsO}_{2}-\mathrm{KI}-\mathrm{H}_{2} \mathrm{O}$ presented in the literature. That is the donor strength of the molecules participating in process influences to the constant of sodium nitrite oxidation by oxygen rate.

In the process of $p$-dihlorbenzene oxidising dechlorinating, as it seen from the data presented in figure 1, the copper complexes (II, I) are compounds accelerating process also.

$\mathrm{UV}$-spectroscopic research of $\mathrm{CuCl}$ solutions in chloride solutions of various acidity has been conducted for an establishment of copper (II, I) complexes structure depending on $\mathrm{C}_{\mathrm{HCl}}$. Measurements spent in area from 200 to 1200 nanometers using spectophotometer Shimadzu with use quartz cuvet with volume $1 \mathrm{~cm}^{3}$ (figure $3 \mathrm{a}$ ).

The displacement of an absorption band is observed at $\lambda=700 \mathrm{~nm}$ to the short-wave part at the increase of hydrochloric acid concentration in the $\mathrm{C}_{\mathrm{HCl}}$ interval from 0.2 to $1,097 \mathrm{~mol} / 1$ that, possibly, is connected with formation of of cop- per (I) complexes of type $\mathrm{CuCl}_{2}^{-}$and $\mathrm{CuCl}_{3}^{2-}$ more complexed by chlorides-ions. The formation of multinuclear complexes $\mathrm{Cu}_{2} \mathrm{Cl}_{4}^{2-}$ and $\mathrm{Cu}_{3} \mathrm{Cl}_{\mathrm{n}+3}^{3-}$ is observed at $\mathrm{C}_{\mathrm{HCl}}>1 \mathrm{~mol} / 1[1,2]$. The coordinatively saturated forms of $\mathrm{CuCl}_{4}^{3-}$ are not observed at $\mathrm{C}_{\mathrm{HCl}} \leq 5 \mathrm{~mol} / \mathrm{l}$. The diagramme of various copper(I) chloride complexes shares distribution $\left(\chi_{i}\right)$ depending on concentration of the hydrochloric acid calculated for complexes $\mathrm{CuCl}_{2}^{-}$and $\mathrm{Cu}_{2} \mathrm{Cl}_{4}^{2-}$ is presented in figure $3 \mathrm{~b}$ (the bottom part). Functions $\mathrm{W}_{\mathrm{O}_{2}}=\mathrm{f}\left(\mathrm{C}_{\mathrm{HCl}}\right)$ are compared with function $\chi_{\mathrm{j}}=\mathrm{f}\left(\mathrm{C}_{\mathrm{HCl}}\right)$. The function $\chi_{\mathrm{Cu}_{2} \mathrm{Cl}_{4}^{2-}}=\mathrm{f}\left(\mathrm{C}_{\mathrm{HCl}}\right)$ possesses biggest symbasis, that is, $p$-dihlorbenzene oxidising dechlorinating rate accrues with formation of bi nuclear complex $\mathrm{Cu}_{2} \mathrm{Cl}_{4}^{2-}$ by (6).

$$
\begin{aligned}
& \mathrm{CuCl}+\mathrm{HCl} \stackrel{\alpha_{1}}{\longleftrightarrow} \mathrm{CuCl}_{2}^{-}+\mathrm{H}^{+} \\
& \mathrm{CuCl}_{2}^{-}+\mathrm{CuCl}_{2}^{-} \stackrel{\alpha_{2}}{\longleftrightarrow} \mathrm{Cu}_{2} \mathrm{Cl}_{4}^{2-}
\end{aligned}
$$




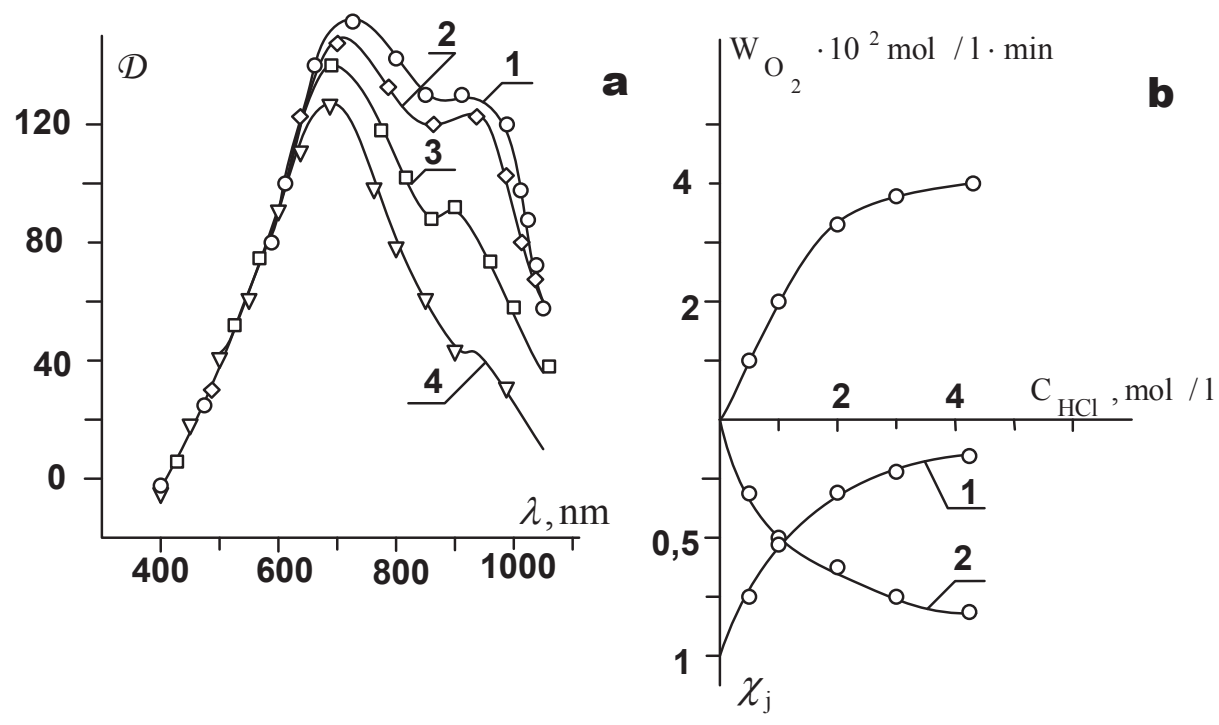

Figure 3 - Oxidizing $p$-dihlorbenzene dechlorinating in the solution: $\mathrm{CuCl}-\mathrm{HCl}-\mathrm{NaNO}_{2}-p-\mathrm{DCB}-\mathrm{H}_{2} \mathrm{O}$

Oxidation conditions: $\mathrm{P}_{\mathrm{O}_{2}}=$ laтм. $\mathrm{T}=333 \mathrm{~K}, \tilde{N}_{\mathrm{CuCl}}=0.3 \cdot 10^{-2} \mathrm{~mol} / \mathrm{l}$;

Absorption spectra: $\mathrm{C}_{\mathrm{HCl}}: 1 .-0.2 ; 2 .-0.55 ; 3 .-2.20 ; 4 .-4.40 \mathrm{~mol} / \mathrm{l}$; $\mathrm{j} \chi: 1 .-2 \mathrm{CuCl}_{2}^{-} \cdot-\mathrm{Cu}_{2} \mathrm{Cl}_{4}^{2-}$

Additional data about influence of copper (I) complexes structure on the $p$-dihlorbenzene oxidising dechlorinating kinetics are presented in figures 1 and 4. Conversion curves in co-ordinates
$\mathrm{W}_{\mathrm{O}_{2}}=\mathrm{f}\left(\mathrm{Q}_{\mathrm{O}_{2}}\right) \quad$ (figure 1) differ by initial concentration of copper (I) chloride in solution $\mathrm{CuCl}$ in the $\mathrm{C}_{\mathrm{CuCl}}$ interval from $0.5 \times 10^{-2}$ to $6 \times 10^{-2} \mathrm{~mol} / \mathrm{l}$.
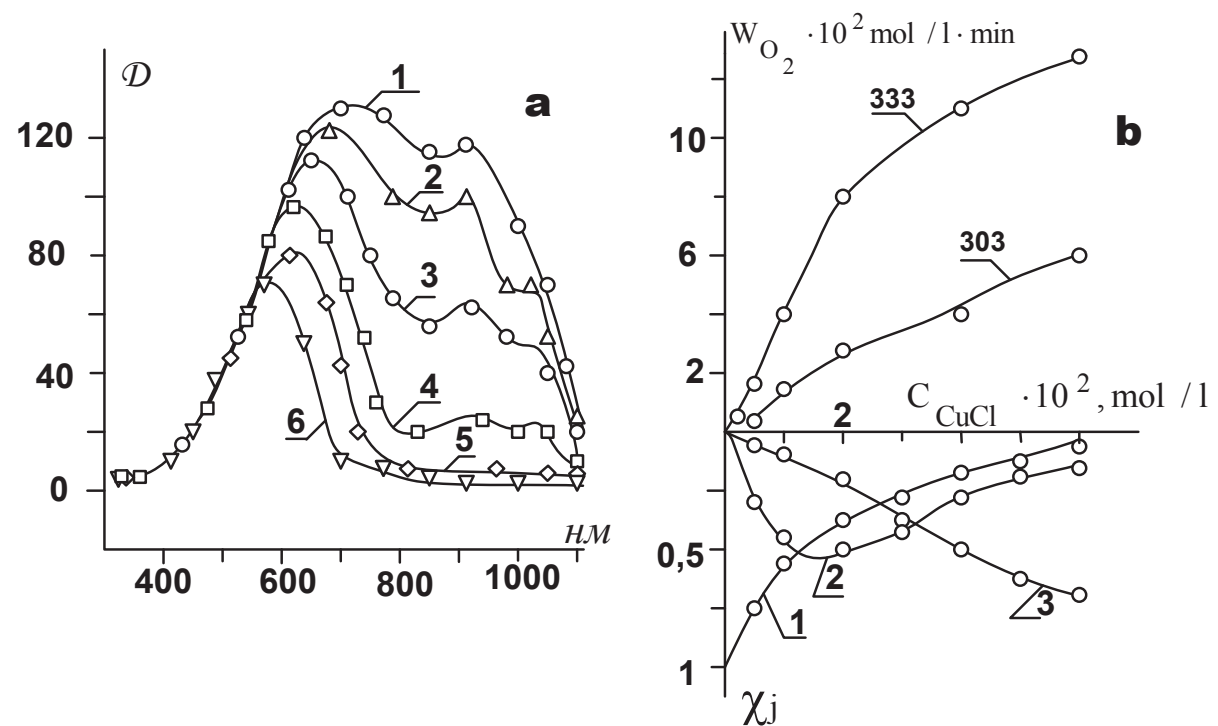

Figure 4 - Oxidizing $p$-dihlorbenzene dechlorinating in the solution: $\mathrm{CuCl}-\mathrm{HCl}-\mathrm{NaNO}_{2}-p-\mathrm{DCB}-\mathrm{H}_{2} \mathrm{O}$ Oxidation conditions: $\mathrm{P}_{\mathrm{O}_{2}}=$ laTM. $\mathrm{T}=333 \mathrm{~K}, \mathrm{C}_{\mathrm{HCl}}=0,55 \mathrm{~mol} / 1 ; \mathrm{C}_{\mathrm{NaNO}_{2}}=10^{-1} \mathrm{~mol} / 1 ; \mathrm{C}_{\mathrm{CuCl}} \cdot 10^{2}: 1 .-0,3 ; 2 .-0,3$; 3.- 1,$0 ; 4 .-2,0 ; 5 .-4,0 ; 6 .-6,0 \mathrm{~mol} / \mathrm{l}$;

a) UV-spectra b) $\chi_{\mathrm{j}}$ : 1. $-\mathrm{CuCl}, 2 .-\mathrm{CuCl}_{2}, 3 .-\mathrm{Cu}_{2} \mathrm{Cl}_{4}$. 
The influence of copper (I) chloride concentration for oxygen absorption rate and quantity of the absorbed oxygen in the process of $p$-dihlorbenzene oxidising dechlorinating is studied in the $\mathrm{C}_{\mathrm{CuCl}_{2}}$ interval from $1 \cdot 10^{-3}$ to $1 \cdot 10^{-2} \mathrm{~mol} / \mathrm{l}$. The selectivity of process does not change; the quantity of the absorbed oxygen remains to constants in the studied $\mathrm{C}_{\mathrm{CuCl}}$ interval and corresponds to the scheme (4).

The dependence of oxygen absorption rate in the solution $p$-DHB-TBF- $\mathrm{HCl}-\mathrm{CuCl}_{2}-\mathrm{NaNO}_{2}-$ $\mathrm{H}_{2} \mathrm{O}$ from initial concentration of copper chloride is described by the equation:

$$
\mathrm{W}_{\mathrm{O}_{2}}=\frac{\mathrm{k}_{1} \cdot \mathrm{C}_{\mathrm{CuCl}_{2}} \cdot \alpha_{1}+\mathrm{k}_{2} \cdot \mathrm{C}_{\mathrm{CuCl}_{2}}^{2} \cdot \alpha_{1} \cdot \alpha_{2}}{1+\alpha_{1} \cdot \mathrm{C}_{\mathrm{CuCl}_{2}} \cdot \mathrm{C}_{\mathrm{CuCl}_{2}}^{2} \cdot \alpha_{1} \cdot \alpha_{2}}
$$

The UV-spectra of the copper (I) chloride complexes received at different initial concentration of $\mathrm{CuCl}$ in the solution $\mathrm{CuCl}-\mathrm{HCl}-\mathrm{H}_{2} \mathrm{O}$ are presented in figure 4a. As well as on the previous spectra, moderate bands with a maximum $\sim 600 \mathrm{~nm}$ and ill-defined shoulder at $\sim 900 \mathrm{~nm}$ are observed in 1 area from 200 to $1200 \mathrm{~nm}$. The intensive band around 700 nanometers moves in near UV-area of a spectrum with increase of $\mathrm{C}_{\mathrm{CuCl}}$ that is characteristic for dimeric copper (I) complexes with the chlorideion in quality of bridging ligand $[3,4]$.

Constants of the equibalances (5)-(6) calculated on data of the $\mathrm{C}_{\mathrm{CuCl}}$ and $\mathrm{C}_{\mathrm{CuCl}_{2}}$ influence on the $p$-dihlorbenzene oxidising dechlorinating kinetics and on spectrophotometrical data are compared below:

\begin{tabular}{lcc} 
Method & $\beta_{1}, 1 / \mathrm{mol}$ & $\beta_{2}, 1 / \mathrm{mol}$ \\
& $\mathrm{C}_{\mathrm{CuCl}}$ & influence data \\
Spectrophotometr. & 402 & 15.23 \\
Kinetics & 103 & 87 \\
& \multicolumn{2}{c}{$\mathrm{C}_{\mathrm{CuCl}_{2}}$ influence data } \\
Spectrophotometr. & 240.3 & 54 \\
Kinetics & 233.0 & 110
\end{tabular}

The distinction of binuclear complexes formation constants $\left(\beta_{2}\right)$ found on the basis of the kinetic and spectrophotometrical data attracts attention. At that $\beta_{2}$ for copper (II) complexes more than for copper (I) halogenides that does not contradict an electronic and structural condition of copper complexes. It is necessary to notice that under all identical concentration conditions nitrogen oxides in the form of $\mathrm{NaNO}_{2}, \mathrm{HNO}_{2}, \mathrm{NO}^{+}, \mathrm{NO}_{2}, \mathrm{NO}$ which added in a solution directly ahead of kinetic characteristics reading participated in a solution in a kinetic method additionally besides copper halogenides and hydrochloric acid. The given experiment testifies that nitrogen oxides influence to oxidising condition of copper and to binuclear halide complexes formation that indirectly point at nitrogen oxides intromission in inner sphere of copper complexes.

The diagram of copper complexes distribution presented in figure $4 \mathrm{~b}$ (the bottom part) gives the possibility to assume that binuclear copper complexes are responsible for oxygen activation in the process of $p$-dihlorbenzene oxidising dechlorinating.

The results showing influence of $p$-dihlorbenzene concentration to oxygen absorption rate are presented in figure 5 . The quantity of the absorbed oxygen in a solution increases with $\mathrm{C}_{p-\mathrm{DCB}}$ increasing. IR-spectra show reduction and in the end of experience disappearance of absorption bands around $600-660 \mathrm{~cm}^{-1}$ characteristic for $\mathrm{C}-\mathrm{Cl}$-bond in $p$-dihlorbenzene and occurrence and increasing of the absorption band around $1720 \mathrm{~cm}^{-1}$ characteristic for $\mathrm{ArC}=\mathrm{O}$.

The $p$-dihlorbenzene influence to UV-spectra of copper chlorides is presented in figure 5a. UVspectra do not change with $p$-DCB introduction as for chlorides of copper (I) and copper (II), only intensity of both bands at $650 \mathrm{~nm}$ and $900 \mathrm{~nm}$ changes with $\mathrm{C}_{\mathrm{DCB}}$ increasing.

The reaction order on oxygen is close to the first, the system potential does not depend from $\mathrm{PO}_{2}$ in the conditions presented in figure 6 . Relation of the rate constant with the oxygen concentration in a solution looks like:

$$
\mathrm{k}=\frac{\mathrm{k}_{0} \gamma \mathrm{C}_{\mathrm{O}_{2}}}{1+\gamma \mathrm{C}_{\mathrm{O}_{2}}}
$$

where $\mathrm{k}_{0}=0,07 \mathrm{c}^{-1}, \gamma=7,9 \cdot 10^{2} 1 / \mathrm{mol}$. These values point at that steady enough complex is formed among oxygen and a reducer. 


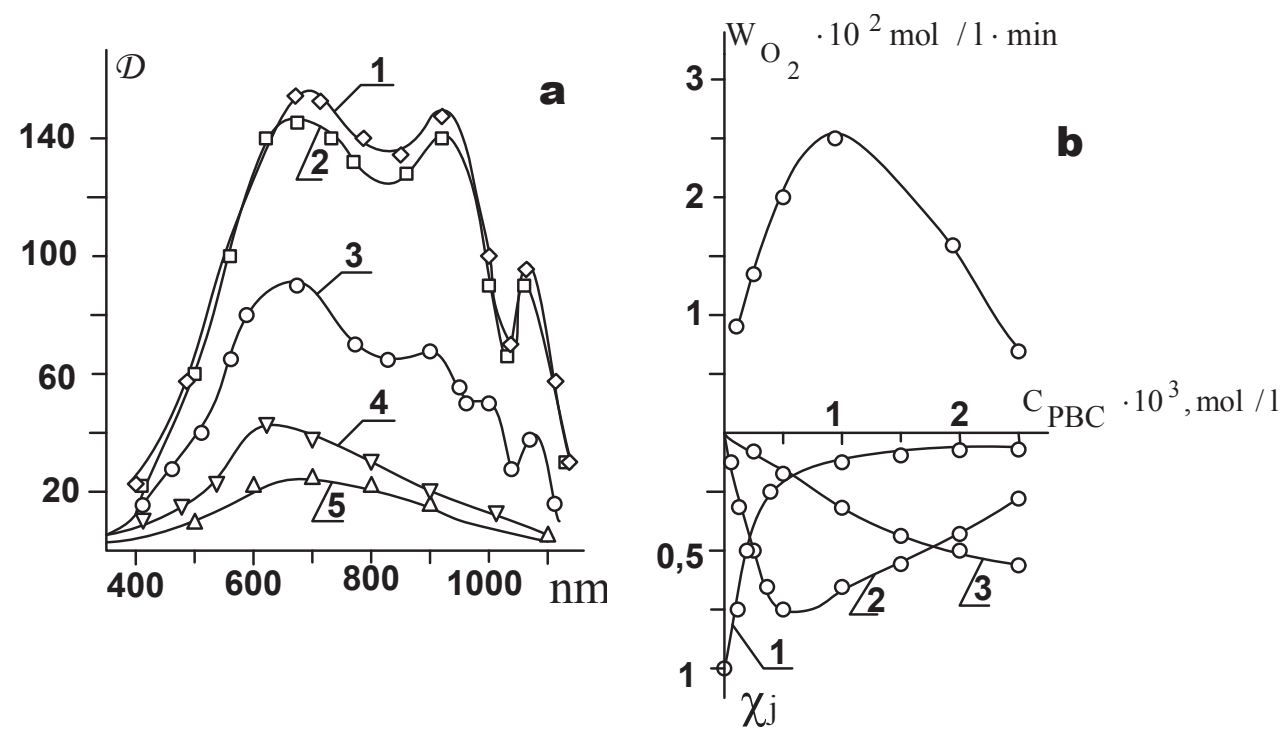

Figure 5 - Oxidizing $p$-dihlorbenzene dechlorinating in the solution $\mathrm{HCl}-\mathrm{CuCl}-\mathrm{NaNO}_{2}-p-\mathrm{DCB}-\mathrm{H}_{2} \mathrm{O}$ Oxidation conditions: $\mathrm{T}=333 \mathrm{~K} ; \mathrm{P}_{\mathrm{O}_{2}}=$ latm. $\left.\mathrm{C}_{\mathrm{HCl}}=1,0 \mathrm{~mol} / 1, \mathrm{C}_{\mathrm{CuCl}_{2}}=3 \cdot 10^{-3} \mathrm{~mol} / \mathrm{l} \mathrm{a}\right) \mathrm{UV}$-spectra: $\mathrm{C}_{\mathrm{HCl}}=0,55 \mathrm{~mol} / 1 ; p-\mathrm{DCB} \cdot 10^{3} ; 1-0,1 ; 2-0,2 ; 3-1,0 ; 4-2,0 ; 5-3,0 \mathrm{~mol} / 1 ; \chi_{\mathrm{j}}: 1-\mathrm{CuCl}, 2-\mathrm{CuCl}_{2}^{-}, 3-\mathrm{Cu}_{2} \mathrm{Cl}_{4}^{2-}$<smiles>Cl[GeH]Cl</smiles>

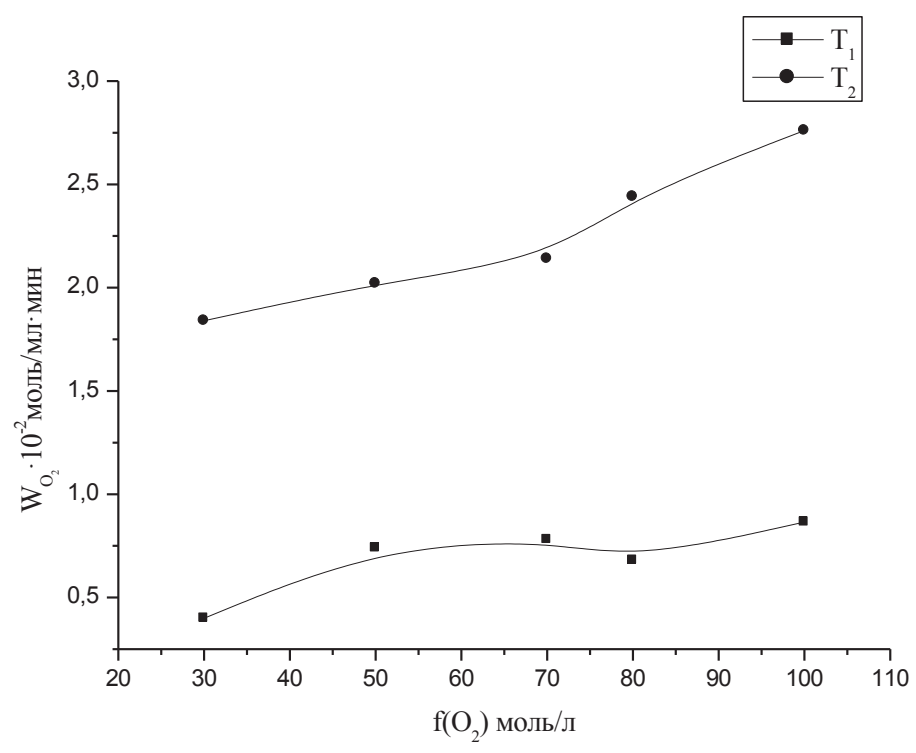

Figure 6 - The dependence of $p$-dihlorbenzene oxidising dechlorinating rate from $\mathrm{O}_{2}$ concentration in system $p$-DCB$\mathrm{TBP}-\mathrm{HCl}-\mathrm{CuCl}_{2}-\mathrm{NaNO}_{2}-\mathrm{O}_{2}-\mathrm{H}_{2} \mathrm{O}$ $\mathrm{T}=333 \mathrm{~K}, \mathrm{~T}_{1}=303 \mathrm{~K}, \mathrm{Ro}_{2}=93,3 \mathrm{kPa}$, modulation frequency $30 \mathrm{kHz}$, irradiation time $25 \mathrm{~min} . \mathrm{C}_{\mathrm{CuCl}_{2}}=0,5 \cdot 10^{-3} \mathrm{~mol} / 1$, $\mathrm{C}_{p-\mathrm{DCB}}=1,0 \cdot 10^{-4} \mathrm{~mol} / 1, \mathrm{C}_{\mathrm{NaNO}_{2}}=2,0 \cdot 10^{-1} \mathrm{~mol} / 1$ $\mathrm{CO}_{2}(\%):$ 1) 30 ; 2) 50; 3) 70; 4); 5) 80; 6) 100. 
The received results allow to assume that $p$-dihlorbenzene oxidising dechlorinating is carried out through formation and redox-disintegration of the intermediate complex including dimeric complex of copper (II, I)chloride, nitrogen oxide and $p$-dihlorbenzene:

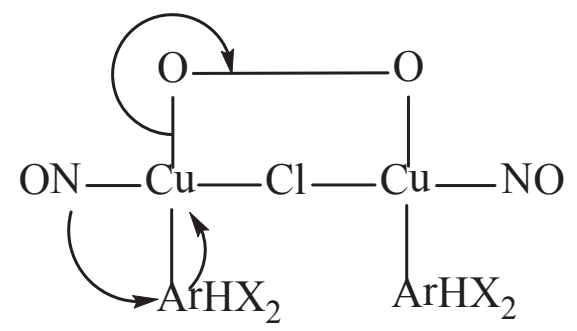

The formation of $\pi$-complex $\mathrm{NO}^{+}$with electrondonating substrata, as a rule, passes easily inasmuch as bond energy of $\mathrm{NO}^{+}$with nucleophiles of arenes type surpasses their protonation energy thanks<smiles>O=[N+]([O-])c1ccc([N+](=O)[O-])cc1</smiles>

$\mathrm{Cl}$

$\mathrm{Cl}$

\section{References}

1 Hoh H. Molecular orbital calculations of Cu-halides // Z. Naturforsch, 1981. - Vol. 36, №10. - P. 1095-1099.

2 Vanliere M., Devore T.C. The infrared spectrum of $\mathrm{CuCl}$ and $\mathrm{CuCl}_{2} / /$ High Temp. Sci., 1984. - Vol. 18, №3. - P. 185-195. to participation of the vacant $\pi^{*}$-orbital of $\mathrm{NO}$ in formation of $\pi$-complex. Their polymerization in s-complex or coordination with transitive metals defines rate of interaction $\mathrm{NO}^{+}$with less active nucleophiles. Formed nitrosocompounds are capable to be easily oxidized to nitrocompounds for the account of dislocating of electronic density from an organic part to NO-group.

The received results allow to assume that as a result of $p$-dihlorbenzene oxidising dechlorinating in system $p$-DHB-TBP- $\mathrm{HCl}-\mathrm{CuCl}_{2}-\mathrm{NaNO}_{2}-\mathrm{O}_{2}-\mathrm{H}_{2} \mathrm{O}$, there is nitration to $m$-position in the beginning, hydrolysis of the chloride ions with the formation of nitro-1,4-dihydroxybenzene and its oxidation to nitro-1,4-benzoquinone. The oxygen is spent at nitration of 1,4-p-dihlorbenzene and for oxidation of dihydroxybenzene to benzoquinone. Nitrogroup presence facilitates chlorine nucleophilic replacement by hydroxogroups in $p$-dihlorbenzene.<smiles>O=C1C2C(=O)C([N+](=O)[O-])C1C([N+](=O)[O-])C2=O</smiles>

3 Fritz J.J. Chloride complexes of $\mathrm{CuCl}$ in agueous solutions // J. Phys. Chem., 1980. - Vol. 84, №18. - P. 2241-2246.

4 Fontana A., van Muylder J., Winand R. Etude spectrophotometrique de solutions agueuses chlorurees de chloture cuireux, a concentrations elevees // Hydrometallurgy, 1983. - Vol. 2, №2. - P. 297-314.

В.С. Емельянова, Ж.Қ. Қайырбеков, Т.В. Шакиева, Н. Немыкина, Б.Т. Досумова, Ұ.Н. Джатқамбаева Азот (II, IV) оксиді мен мыс (II) комплекстерінің қатысуымен п-дихлорбензолды тотықтыра дехлорлау

Мақалада п-дихлорбензолды $\mathrm{CuCl}_{2}-\mathrm{TБ} \Phi-\mathrm{NaNO}_{2}-\mathrm{O}_{2}-\mathrm{H}_{2} \mathrm{O}$ ерітіндіде дехлорлау процесінің кинетикасын зерттеу нәтижелері көрсетілген. Дехлорлау процесіне жүйедегі барлық компоненттердің әсері зерттеліп көрсетілген. Реакцияға қатысатын мыс аралық комплекстерінің құрамы УК-спектрлер көмегімен зерттелген. Каталитикалық аралас комплекстерінің құрамындағы биядролық мыс комплекстерінің қатысатыны анықталып, олардың кинетикалық және спектрофотометрлі әдістер арқылы бағаланып, салыстырылды. Ерітіндінің құрамы өзгергеніне байланысты биядерлік комплекстердің жиналу диаграммалары көрсетілген. Процеске жауапты аралық комплекстердің құрамы анықталған, механизм сызбанұсқасы ұсынылған. Аралық комплекстің тотығу- 
тотықсыздану ыдырауынан тұратын п-дихлорбензолды дехлорлау процесінің шектік сатысы анықталған. Бұл аралық комплекс димерлі мыс (I,II) хлориды, азот оксиды мен п-дихлорбензолдан тұрады.

Tүйін сөздер: тотығу, дехлорлау, п-дихлорбензол, катализатор, кинетика, механизм.

В.С. Емельянова, Ж.К. Каирбеков, Т.В. Шакиева, Н. Немыкина, Б.Т. Досумова, У.Н. Джаткамбаева Окислительное дехлорирование $n$-дихлорбензола в присутствии комплексов меди (II) и оксидов азота (II, IV)

В статье представлены результаты исследования кинетики дехлорирования п-дихлорбензола в растворе $\mathrm{CuCl}_{2}-$ ТБФ- $\mathrm{NaNO}_{2}-\mathrm{O}_{2}-\mathrm{H}_{2} \mathrm{O}$. Изучено и количественно описано влияние всех компонентов системы на процесс дехлорирования. С помощью УФ-спектроскопии изучен состав промежуточных комплексов меди, участвующих в реакции. Установлено участие биядерных медных комплексов в составе каталитических промежуточных комплексов, константы образования которых оценены и сопоставлены с помощью кинетического и спектрофотометрических методов. Определён состав промежуточных комплексов, ответственных за процесс, предложена схема механизма, определена лимитирующая стадия дехлорирования п-дихлорбензола, включающая редоксраспад промежуточного комплекса, который включает в себя димерный комплекс хлорида меди (II, I), оксид азота и п-дихлорбензол.

Ключевые слова: окисление, дехлорирование, п-дихлорбензол, катализатор, кинетика, механизм. 